\title{
The Influence of Segregation Size of Peat and Pre- Consolidation Pressure on the Effective Shear Strength Properties
}

\author{
Norhaliza Wahab $^{1,2^{*}}$, Mohd Khaidir Abu Talib ${ }^{1,2}$ \\ ${ }^{1}$ Research Center for Soft Soil, Universiti Tun Hussein Onn Malaysia, 86400 Batu Pahat \\ Johor, Malaysia \\ ${ }^{2}$ Faculty of Civil and Environmental Engineering, Universiti Tun Hussein Onn \\ Malaysia, 86400 Batu Pahat Johor, Malaysia
}

\begin{abstract}
The degree of composition for peat soil in geotechnical engineering may affected the shear strength of the peat soil based on their types (sapric, hemic and fabric). The strength was affected by many factors such as its origin, water content, organic matter and arrangement of peat fibric. The aims of this paper was to investigate the influence of segregation peat sizes and pre- consolidation pressure on the effective shear strength properties of reconstituted peat $1.000 \mathrm{~mm}(<\mathrm{RS} 1.00)$ and reconstituted peat $2.360 \mathrm{~mm}(<\mathrm{RS} 2.36)$. All the reconstituted peat samples were segregated through passing opening sieve size $1.00 \mathrm{~mm}$ and 2.36 $\mathrm{mm}$ with the aid of water to obtain homogeneous reconstituted peat slurry and were pre-consolidated with $50 \mathrm{kPa}, 80 \mathrm{kPa}$ and $100 \mathrm{kPa}$ pressure to obtain samples for triaxial tests. The Triaxial Consolidated Undrained Test was selected to test the shear strength properties of the reconstituted peat samples by using confining pressure $25 \mathrm{kPa}, 50 \mathrm{kPa}$ and $100 \mathrm{kPa}$. Both of the effective shear strength properties result such as cohesion and angle of friction obtained recorded $<\mathrm{RS} 2.36$ has higher strength than $<$ RS1.00. The main factors that contribute to the differences shear strength value between two size reconstituted peats were segregation of peat size which affected by peat size (fiber size) and also preconsolidation pressure applied which reduced the voids, water content and also improved the stiffness and strength of the specimen. All specimen and testing was conducted at RECESS, UTHM.
\end{abstract}

\section{Introduction}

Wetlands International Malaysia [1,2] states peat soil is a soil formed by dead wetland plants materials that cannot decay in a normal way because of the presence of high water table. Malaysia has a total of about 2.6 million hectares of peatland, 0.7 million hectares in Peninsular Malaysia, 1.7 million hectares in Sarawak and 0.2 million hectares in Sabah. In Peninsular Malaysia, the peat areas are found in the east and west coast areas, especially in the coastal areas of West Johore, Kuantan and Pekan district, Rompin-Endau area, Northwest Selangor and the Perak (Hilir 
Perak district and Perak Tengah district). In Sarawak, peat occurs mainly between the lower stretches of the poorly drained interior valleys (valley peat) and the main river course (basin peat). Peat is found in the administrative division of Sri Aman, Sibu, Sarikei, Bintulu, Miri, Kuching, Samarahan and Limbang. In Sabah, the organic soils are found around the coastal areas of the Klias peninsur, Krah swamps in Sugut, Kota Belud and Labuk estruaries and Kinabatangan floodplains. The content of peat differs from location to location due to factor such as the origin of fiber, temperature and degrees of humification [3].

In geotechnical engineering, soil containing more than $20 \%$ organic is considered as organic soil. Due to this condition, peat which has more than $75 \%$ organic content is classified as organic soil [3]. For geotechnical purposes, Magnan [4] has divided the decomposition of peat into 3 types which are fibrous (least decomposed) tentatively ranging from $\mathrm{H} 1$ to $\mathrm{H} 3$, Hemic (intermediate decomposed) in the range $\mathrm{H} 4$ to $\mathrm{H} 6$ and Sapric (most decomposed) ranging $\mathrm{H} 7$ to $\mathrm{H} 10$. According to Levesque and Dinel [5], wet sieving method was practically to be applied in determining the particle size distribution of peat fiber. Based on Levesque and Dinel (1977), particle- size distribution of peat fiber was determined according to the wet sieving method. For the case of organic soils, particles size distribution is not necessarily used in characterization and it is highly influenced by its botanic nature. As for mineral soil, the theory of particle composed of single grain unit is not able to be visualized in an organic area. Therefore, it could be practical to use particle size as the comparison for fibrous and non-fibrous peat materials which denote their decomposition level. Wet sieving is chosen to separate fine grains from the coarse grains and it is carried out onto the disturbed or undisturbed soil by using tap water with the arrangement of a stack of aperture sizes which chosen. Tang [6] revealed the wet sieve method is more effective to practice for coarse peat soil and the soil fraction finer than $63 \mu \mathrm{m}$ was analyzed with diffraction laser method (cilas test). Mohamad [7] identified that the Parit Nipah peat is well- graded soil and behaves in various shapes and sizes.

Shear strength of a soil mass is defined as the internal resistance per unit area the soil mass can offer to resist failure and sliding along any plane inside it [8]. The shear strength properties of effective cohesion and effective angle of friction can be obtained from a set of triaxial compression tests by plotting the Mohr circles of effective stress representing the selected failure condition and drawing the envelope to them. Failure can happen in the soil as a whole, or within limited narrow zones referred to as failure planes. Ajlouni [9] interpret the undrained shear strength of peat is a critical parameter as other soil. A slide or soil collapse can occur due to the lower bearing capacity which contributed by low shear strength, high settlement and high compressibility of peat [10].

In general, highly decomposed peat has higher shear strength than lowly decomposed peat [11]. There are few methods that can strengthen the soils such as Soil composition (shape, size, and distribution), soil structure (undisturbed, disturbed, remolded, compacted, void and cementation), initial state (loose or dense sample) and type of loading (drained or undrained) [12]. Huat [3] found the undrained friction angle of peat in West Malaysia is in the range between $3^{\circ}$ to $25^{\circ}$ while O'Kelly and Orr [13] postulate that the cohesion value of fibrous peat is higher than zero. In this paper, the effect of the segregation peat and preconsolidation pressures on reconstituted peat $1.00 \mathrm{~mm}(<\mathrm{RS} 1.00)$ and reconstituted peat $2.36 \mathrm{~mm}(<\mathrm{RS} 2.36)$ was evaluated to determine the shear strength properties. 


\section{Samples and Methods}

\subsection{Disturbed Peat Sample}

Peat samples were taken from Parit Nipah Darat, Batu Pahat, Johor at the depth from 0.3 to $1.0 \mathrm{~m}$ below ground surface and classified as moderately decomposed (H5) based on Post classification. Once the peat samples were taken, it was being stored in a sealed container to make sure the samples is enough for all reconstituting sampling and conducting physical testing.

\subsection{Reconstituted Peat Sample}

The disturbed peat samples were gently pressed and rubbed to pass $1.00 \mathrm{~mm}$ and $2.36 \mathrm{~mm}$ sieves with the aid of water to obtain homogeneous reconstituted peat slurry as shown in Figure 1 (a). The sieve sizes were selected based on the maximum particle size passing sieve conducted for this review. Later, the homogeneous slurry that retained and deposited in the plastic box as shown in Figure 1 (a) were transferred and filled in specific cylindrical tubes that were around $120 \mathrm{~mm}$ in diameter and $400 \mathrm{~mm}$ in height with porous stone were placed at the upper and bottom of the sampler to allow the water flow through it. The samples than were subjected under certain consolidation pressure that were $50 \mathrm{kPa}, 80 \mathrm{kPa}$ and $100 \mathrm{kPa}$. The reconstitution of peat samples was assumed complete when there is no more water drained out from the bottom tube of the remolded sample equipment and no more settlement of the soil in the tube as shown in Figure 1 (b). Next, the sharp edge of PVC tubes sized $50 \mathrm{~mm}$ in diameter and $100 \mathrm{~mm}$ in height were used to extrude the reconstituted peat samples with the aid of soil extruder. Then the extruded samples were trimmed using trimming equipment to obtain samples for triaxial tests. The excessive reconstituted peat samples were collected to identify the physical properties.

The consolidation sample is assumed complete when there is no more water drained out from the bottom tube of the remolded sample equipment and no more settlement of the soil in the tube

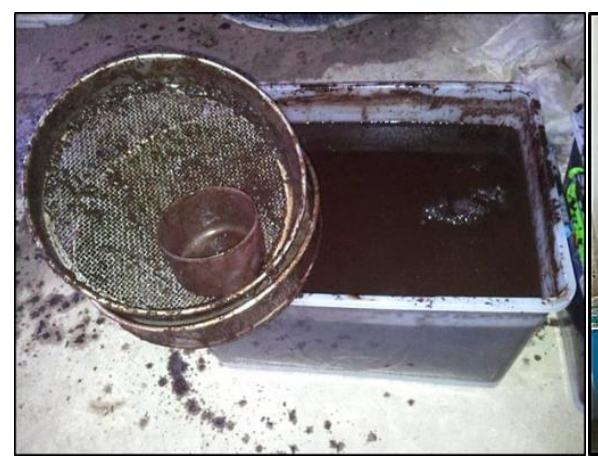

(a)

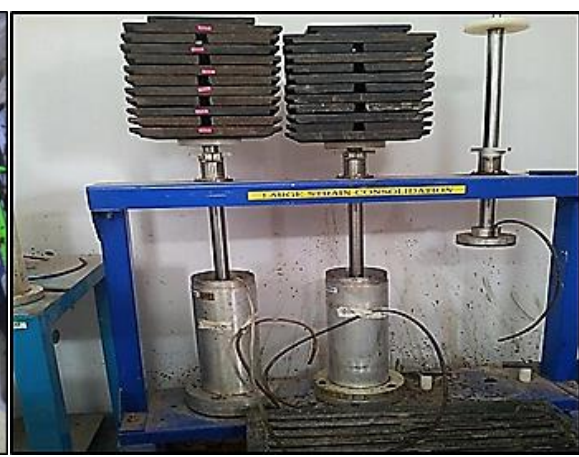

(b)

Figure 1. (a) Segregation Peat Sizes through Wet Sieving Method (b) PreConsolidated Reconstituted Peat Method (Metal Load) 


\subsection{Triaxial Consolidated Undrained Test (CU- Test)}

A Monotonic Triaxial machine was used to determine the shear strength properties of the reconstituted peat. The reconstituted sample with the size of $50 \mathrm{~mm}$ in diameter and $100 \mathrm{~mm}$ in height was inserted into a rubber membrane with two rubber O-rings at the top cap and the others two at the bottom cap to avoid the air bubble and water enter the sampler during testing. The sample is placed centrally on the base pedestal of the triaxial cell, ensured that it is incorrect vertical alignment. The cell body is assembled with the loading piston well clear of the specimen top cap. Then, the distilled water was filled into the triaxial cell and precaution was taken to avoid air bubble trapped in the sample in minimizing the error readings.

In CU- test, there were three major stages took place: saturation, consolidation and shearing. At the first stage, the reconstituted peat sample was saturated by the increments of $50 \mathrm{kPa}$ cell pressure until the coefficient B achieved 0.95 . In stage two, the reconstituted peat sample was consolidated isotropically for 24 hours. In the last stage, load with the constant strain rate $0.1 \mathrm{~mm} / \mathrm{min}$ was applied until the specimen failed and reached $20 \%$ axial strain. Mohamad [7] states the peat deformation is usually considered be found at around $15 \%$ to $20 \%$ strain. All the reconstituted peat samples were tested by using confining pressure $25 \mathrm{kPa}, 50 \mathrm{kPa}$ and $100 \mathrm{kPa}$ according to BS1377: Part 8: 1990 with excess pore water pressure measurement.

\section{Results and Discussions}

\subsection{Reconstituted Parit Nipah Peat Properties}

Table 1 shows the result of physical properties for $<\mathrm{RS} 1.00$ and $<\mathrm{RS} 2.36$. The moisture content for $<\mathrm{RS} 1.00$ and $<\mathrm{RS} 2.36$ are in the ranges of 330-387\% and $<$ RS2.36 were 354- 406\%, respectively. The liquid limits of samples <RS1.00 and $<$ RS2.36 were 325-332\% and 344-351\%, respectively. The moisture content and liquid limit of the reconstituted peat samples were affected by the segregation of peat sizes and the applied pre-consolidation pressure during reconstitution stages. Kolay and Pui [14] has proclaimed the percentage of moisture content and liquid limit was high because the peat sample contains high fiber which resulted in high water absorption capacity.

Note that, the fiber contents of $<\mathrm{RS} 1.00$ and $<\mathrm{RS} 2.36$ are $13 \%$ and for $36 \%$ respectively. The different percentage of fiber content was due to the peat passing through the aperture size of sieve at the varying size. The differences percentage of fiber content is dependent on the size of fiber and the degree of the decomposition of peat. The higher increasingly degree of decomposition led to the increasingly low fiber content. The wet sieving method may affect the fiber content that caused segregation between the peat fiber. The segregation of peat is representing the peat sizes, and also represents the degree of decomposition of peat. The specific gravity value for $<\mathrm{RS} 1.00$ and $<\mathrm{RS} 2.36$ is in the range with the previous study recorded 1.41 and 1.36 respectively. The higher value of specific gravity was depended on the effect of decomposition level which is the higher degree of decomposition leads to higher specific gravity because was affected by the organic constituents such as cellulose and lignin. 
Table 1. Physical Properties of Reconstituted Parit Nipah Peat

\begin{tabular}{|c|c|c|c|c|c|}
\hline Parameters & $\begin{array}{c}\text { Pre- } \\
\text { Consolidation } \\
\text { Pressure (kPa) }\end{array}$ & $\begin{array}{c}\text { Moisture } \\
\text { Content } \\
(\%)\end{array}$ & $\begin{array}{c}\text { Liquid } \\
\text { Limit } \\
(\%)\end{array}$ & $\begin{array}{c}\text { Fiber } \\
\text { Content } \\
(\%)\end{array}$ & $\begin{array}{l}\text { Specific } \\
\text { Gravity } \\
\left(\mathrm{mg} / \mathrm{m}^{3}\right)\end{array}$ \\
\hline \multirow{3}{*}{$<\mathrm{RS} 1.00$} & 50 & 387 & 332 & \multirow{3}{*}{$\begin{array}{c}13 \text { (Sapric } \\
\text { Peat) }\end{array}$} & \multirow{3}{*}{1.41} \\
\hline & 80 & 368 & 330 & & \\
\hline & 100 & 330 & 325 & & \\
\hline \multirow{3}{*}{$<\mathrm{RS} 2.36$} & 50 & 406 & 351 & \multirow{3}{*}{$\begin{array}{c}36 \text { (Hemic } \\
\text { Peat) }\end{array}$} & \multirow{3}{*}{1.36} \\
\hline & 80 & 377 & 348 & & \\
\hline & 100 & 354 & 344 & & \\
\hline $\begin{array}{c}\text { Past } \\
\text { Researchers } \\
{[3],[15]}\end{array}$ & - & $200-1000$ & $190-360$ & $\begin{array}{c}33 \text { (Sapric) } \\
>33-66 \\
(\text { Hemic) }\end{array}$ & $\begin{array}{l}1.38- \\
1.80\end{array}$ \\
\hline
\end{tabular}

\subsection{Triaxial Consolidated Undrained Analysis}

By determining the peak deviator stress value and excess pore water pressure value in stress- strain relationship and excess pore water pressure- strain relationship, then Mohr- Coulomb Circle was plotted to determined (c' and $\left.\phi^{\prime}\right)$.

\subsubsection{Stress- Strain Relationship and Variation of Excess Pore Water Pressure versus Axial Strain.}

Figure 2 (a) and (b) depict the stress strain relationship in determination of the maximum value of deviator stress $\sigma_{\text {max }}^{\mathrm{d}}$ versus axial strain, $\varepsilon_{\mathrm{a}}$ for reconstituted peat $<$ RS1.00 and <RS2.36. Meanwhile, in Figure 3 (a) and (b) shows the excess pore water pressure relationship of reconstituted peat $<\mathrm{RS} 1.00$ and $<\mathrm{RS} 2.36$ in determination of the excess pore water pressure, $\Delta u$ versus axial strain, $\varepsilon_{\mathrm{a}}$ during the shearing stage. The $\sigma_{\max }^{\mathrm{d}}$ and $\Delta \mathrm{u}$ gradually increase when pre-consolidation pressure, $\sigma_{c}$ and confining pressure $\sigma^{\prime}$ increased for both $<\mathrm{RS} 1.00$ and $<\mathrm{RS} 2.36$ and slightly down toward $20 \%$ axial strain. The increment of the confining pressure was concomitant with the increment of the deviator stress and the excess pore water pressure of undisturbed and reconstituted peat $[16,17,18]$. Due to drainage was not permitted in consolidated undrained test, it caused pore water pressure to increase. Mohamad [7] reveals that pore water pressure was one of formation properties that have a direct impact on shearing loading. The variation of the stress- strain relationship generated increasing deviator stress for loose soil. At the same time, the variation of excess pore water pressure also generated the same pattern. Das [19] has diagnosed and explained the variation of the pore water pressure for loose soil was gradually increased until reach limited strain. This contribution of the differences pattern of deviator stress and the excess pore water pressure relationship was due to segregation of peat size, the shape of particles, peat structure such as undisturbed, disturbed, remolded and compacted, a state of the peat such as loose or dense sample and also the type of loading whether drained or undrained. This factor 
is also explained by Poulos [12] in which the differences of the stress-strain relationship caused by the soil composition, initial state, soil structure and loading condition.

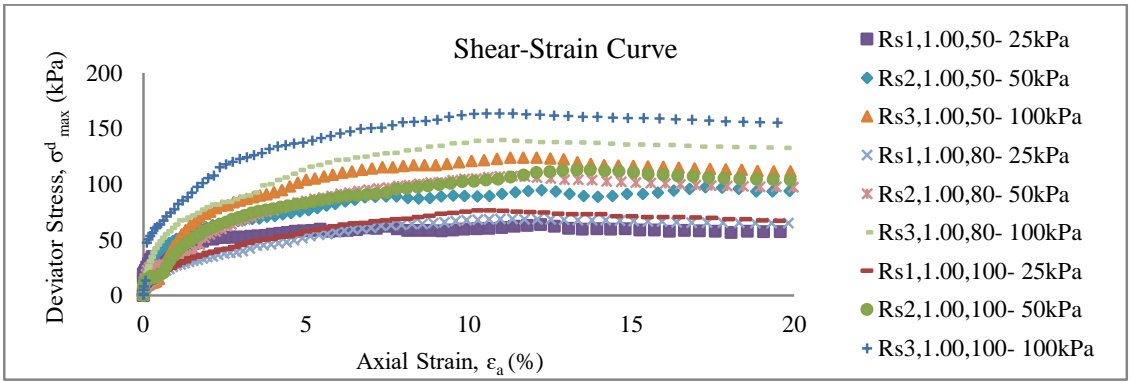

(a)

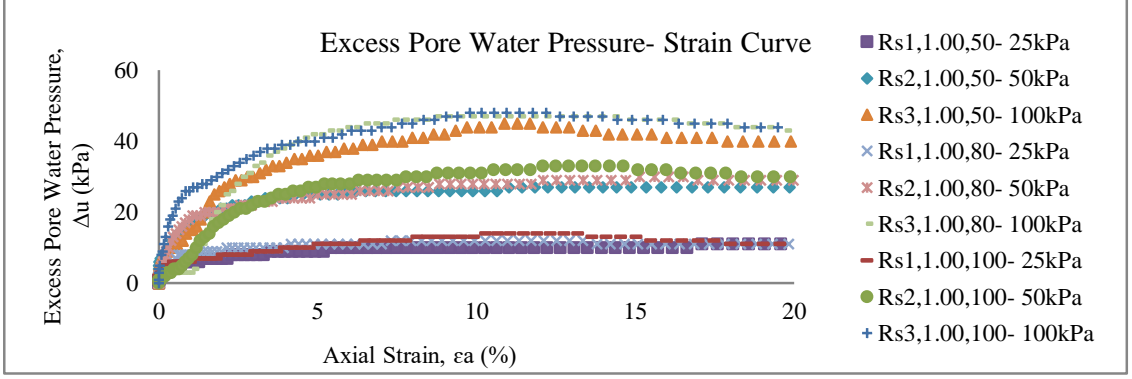

(b)

Figure 2. (a) Graph of Shear- Strain Relationship for <RS1.00, (b) Graph of Excess Pore Water Pressure versus Axial Strain for $<$ RS1.00

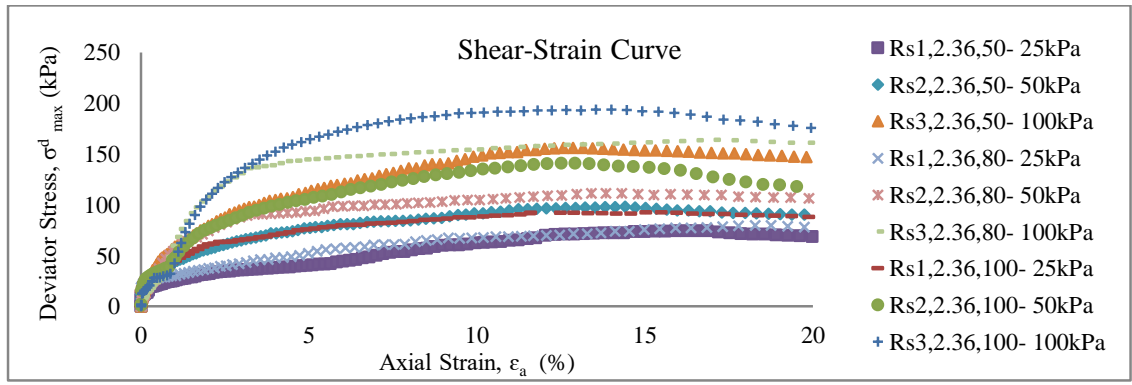

(a)

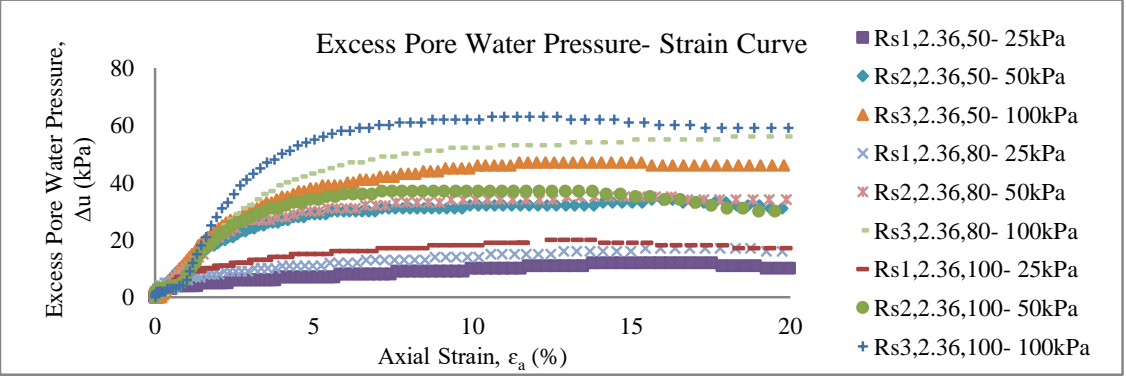

(b) 
Figure 3. (a) Graph of Shear- Strain Relationship for <RS2.36, (b) Graph of Excess Pore Water Pressure versus Axial Strain for $<$ RS2.36

\subsubsection{Effective Shear Strength Properties.}

The results of effective shear strength properties $\left(c^{\prime}\right.$ and $\left.\phi^{\prime}\right)$ for $<\mathrm{RS} 1.00$ and $<$ RS2.36 with the pre-consolidation pressure $50 \mathrm{kPa}, 80 \mathrm{kPa}$ and $100 \mathrm{kPa}$ are tabulated in Table 2 . The cohesion value for $<\mathrm{RS} 2.36$ were recorded as $15 \mathrm{kPa}, 17$ $\mathrm{kPa}$ and $18 \mathrm{kPa}$, and the angle of friction were recorded $30^{\circ}, 33^{\circ}$ and $38^{\circ}$ due to preconsolidation pressures $50 \mathrm{kPa}, 80 \mathrm{kPa}$ and $100 \mathrm{kPa}$, respectively. Similarly, for $<$ RS1.00 the cohesion values were recorded as $13 \mathrm{kPa}, 14 \mathrm{kPa}$ and $14 \mathrm{kPa}$, and the angle of friction values were $26^{\circ}, 28^{\circ}$ and $32^{\circ}$, resulted from the applied preconsolidation pressures. Hence, the shear strength Properties for $<\mathrm{RS} 2.36$ are higher than those of $<\mathrm{RS} 1.00$. Such outcomes were due to the segregation of the peat size and pre- consolidation pressures that were subjected to the reconstituted peat that changed the structure, initial void ratios and moisture contents. The segregation of the peat via wet sieving and the applied pre-consolidation pressure changed the peat structure and allowed the particles of the peat to bind very well with each other. According to O'Kelly and Pichan [20], the compressibility of peat can affect the fabric and the arrangement of the constituent fibers and also inter-particle chemical bonding in the soil. The water content and void ratio for $<\mathrm{RS} 2.36$ were higher than those of $<\mathrm{RS} 1.00$ as shown in the table. This was because the reconstituted peat $<$ RS2.36 contains high hollow fibric compare to the reconstituted peat <RS1.00 which contributed to the high void ratio and able to hold high water content capacity, thus caused low shear strength. However, the water content and void ratio were decreasing with the increasing of $\sigma_{\mathrm{c}}$ values. Such phenomena were observed because the reconstituted peat samples were subjected to high pre-consolidation pressures.

Table 2. Effective Undrained Triaxial Summary Results

\begin{tabular}{|c|c|c|c|c|c|}
\hline \multirow[t]{2}{*}{ Sample } & \multirow[t]{2}{*}{$\begin{array}{c}\sigma_{\mathbf{c}} \\
(\mathbf{k P a})\end{array}$} & \multirow{2}{*}{$\begin{array}{c}\text { Water } \\
\text { Content, } w \\
(\%)\end{array}$} & \multirow[t]{2}{*}{$\begin{array}{c}\text { Void } \\
\text { Ratio, e e }\end{array}$} & \multicolumn{2}{|c|}{$\begin{array}{c}\text { Effective Shear Strength } \\
\text { Properties }\end{array}$} \\
\hline & & & & c' (kPa) $^{\prime}$ & $\phi^{\prime}\left({ }^{0}\right)$ \\
\hline \multirow{3}{*}{$<\mathrm{RS} 1.00$} & 50 & 361.74 & 5.10 & 13 & 26 \\
\hline & 80 & 341.38 & 4.81 & 14 & 28 \\
\hline & 100 & 335.36 & 4.73 & 14 & 32 \\
\hline \multirow{3}{*}{$<\mathrm{RS} 2.36$} & 50 & 379.38 & 5.16 & 15 & 30 \\
\hline & 80 & 356.54 & 4.85 & 17 & 33 \\
\hline & 100 & 345.39 & 4.70 & 18 & 38 \\
\hline
\end{tabular}

3.2.3 Relationship between Effective Shear Strength Properties with segregated of peat size and pre-consolidation pressure, $\sigma_{c}$.

Figure 4 (a) and (b) show the relationship between shear strength parameters of $<\mathrm{RS} 1.00$ and $<\mathrm{RS} 2.36$ with pre- consolidation pressures, $\sigma_{\mathrm{c}} 50 \mathrm{kPa}, 80 \mathrm{kPa}$ and 100 
$\mathrm{kPa}$. Figure 5 shows that the effective shear strength properties cohesion and angle of friction were increased with the increment of the peat sizes and preconsolidation pressure. Barnes [21] has agreed with the statement and stated the higher pre- consolidation pressure used thus associated with the lower void ratio and thus increasing the shear strength due to soil specimen texture was subjected to the higher pre- consolidation pressure. Yusoff et.al [22] identified that the texture of specimen can affect the strength since the sample was compacted. In addition, peat sizes, fabric, shape and packing of the soil particles can affect the soil shear strength [23]. According to Mitchell [24], factors such as shapes, sizes, arrangements and forces between soil particles can contribute to determination of properties values such as strength. Hence, it can be concluded that the peat size (peat fiber) can affect the initial water content, initial void ratio and fiber content, and thus affect the shear strength properties.

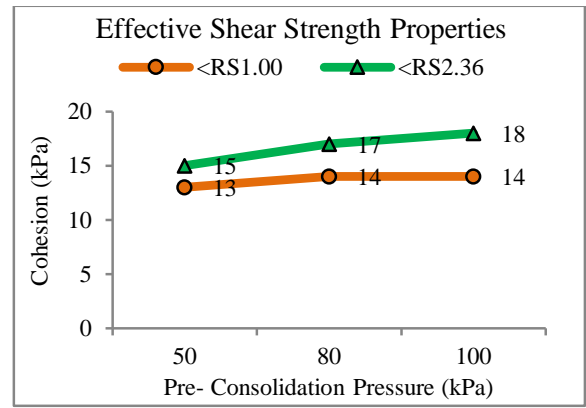

(a)

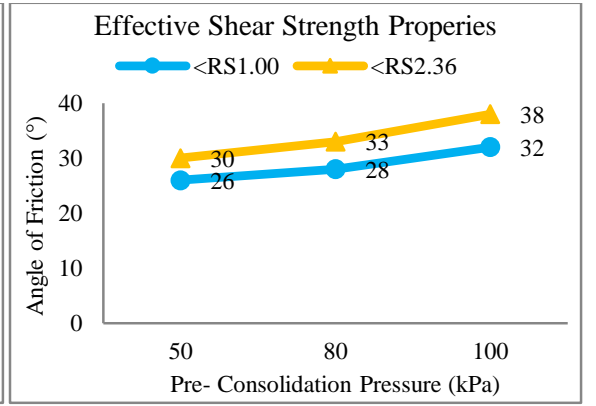

(b)

Figure 4. (a) Relationship of Cohesion Respect to the Peat Sizes and Pre- consolidation Pressure (b) Relationship of Angle of Friction Respect to the Peat Sizes and Preconsolidation Pressure

\section{Conclusions}

In this paper, the effective shear strength properties such as cohesion and angle of friction were investigated to correlate with the influence of the reconstituted method in term of segregation peat size $(<\mathrm{RS} 1.00$ and $<\mathrm{RS} 2.36)$ and also pre- consolidation pressure $(50 \mathrm{kPa}, 80 \mathrm{kPa}$ and $100 \mathrm{kPa})$. The effective shear strength properties of $<$ RS2.36 were higher than those of $<$ RS1.00. The increment of the effective shear strength properties was contributed by the effect of peat size (fiber size) which act as reinforcement, and also the effect of the pre- consolidation pressure of the reconstituted peat sample that reduced the voids, water content and also improved the stiffness and strength of the specimen. The differences in the values of cohesion and angle of friction obtained in this study between those of <RS1.00 and <RS2.36 were greatly governed by a few factors. The factors that contribute to the higher shear strength were sizes of peat fiber, pre- consolidation pressure, initial void ratio and physical properties such as initial water content, fiber content and liquid limit. Thus, it can be concluded that the reconstituted peat with the segregation peat passing sieve sizes $1.00 \mathrm{~mm}$ and $2.36 \mathrm{~mm}$ and pre- consolidation pressures of 50 $\mathrm{kPa}, 80 \mathrm{kPa}$ and $100 \mathrm{kPa}$ can increase the shear strength properties of peat soil due to the strengthen of peat structure after subjected with pre- consolidation pressure and also because of the decomposition peat fiber via segregation peat size. 


\section{Acknowledgment}

The authors would like to express appreciation and special gratitude to the supervisory team for the guidance, encouragement and valuable support and to all the staff members of Pejabat Pendaftar Universiti Tun Hussein Onn Malaysia, Faculty of Civil and Environmental Engineering Department (FKAAS) and Research Center for Soft Soil (RECESS).

\section{References}

1. Wetlands International-Malaysia, A Quick Scan of Peatlands in Malaysia. Project funded by the Kleine Natuur Initiatief Projecten, Royal Netherlands Embassy (2010).

2. CREAM. Guidelines for Construction on Peat and Organic Soils in Malaysia. Kuala Lumpur, Malaysia: Construction Research Institute of Malaysia (CREAM) (2015).

3. Huat, B.B.K., Organic and Peat soil Engineering. University Putra Malaysia, Serdang, Malaysia (2004).

4. Magnan, J.P., Classification geotechnique des sols: 1- A propos del la classification LPC, Bulletin de Liaison des Laboratoiresdes Ponts et Chaussees, Paris, PP. 19- 24 (1980).

5. Levesque, M., and Dinel, H., Fiber Content, Particle- Size Distribution and Some Related Properties of Four Peat Materials in Eastern Canada. Can. J. Soil Sci. 57: 187- 195 (1977).

6. Tang, B. L., Reutilization of Organic and Peat Soils by Deep Cement Mixing. Master's Thesis. UTHM (2011).

7. Mohamad, H.M., Post Cyclic Behaviour of Peat Soil. Master's Thesis. UTHM (2015).

8. Das, B.M., Principles of Foundation Engineering. 7th Ed. United States of America: Christopher M. Shortt (2007).

9. Ajlouni, M. A., Geotechnical Properties of Peat and Related Engineering Problems. PhD Thesis (2000).

10. Kazemian, S., Huat, B. B., Prasad, A., and Barghchi, M. A., A State of Art Review of Peat: Geotechnical Engineering Perspective, International Journal of The Physical Sciences, volume 6 (8), pp. 1974- 1981 (2011).

11. Huat, B.B.K., Asadi, A. and Kazemian, S., Experimental Investigation on Geomechanical Properties of Tropical Organic Soils and Peat. American Journal of Engineering and Applied Sciences 2 (1): 184- 188 (2009).

12. Poulos, S. J., Jansen, R. B., ed., Liquefaction Related Phenomena, Advance Dam Engineering for Design (Van Nostrand Reinhold): 292-320, (1989).

13. O'Kelly, B.C. and Orr, T.L.L., Briefing: Effective Stress Strength of Peat in Triaxial Compression. Proceedings of the Institution of Civil Engineers. Institution of Civil Engineers (ICE). Pp. 417-420, (2014).

14. Kolay, P.K. and Pui, M.P., Peat Stabilization Using Gypsum and Fly Ash. Unimas E Journal of Civil Engineering; Vol 1.Issue 2 (2010).

15. Rahman, J. A. and Chan, C. M., Influence of Temperature on the Mass Loses of Tropical Peat at Different Decomposition Level, Soft Soil Engineering International Conference (2013).

16. Zolkefle S. N. A. The Dynamic Characteristic of Southwest Johor Peat under Different Frequencies. Degree of Master in Civil Engineering Thesis (2014). 
17. Rabbee, T., Rafizul, I. M., Assaduzzaman, M., and Alamgir, M. Investigate the effect of pre-consolidation pressure and organic content on the shear strength and compressibility parameter of reconstituted soil. Int. Journal of Applied Sciences and Engineering Research, Vol. 1, Issue 6 (2012).

18. Cola, S. and Cortellazo, G., The Shear Strength Behaviour of Two Peaty Soils, Geotechnical and Geological Engineering, Pp. 679-695 (2003).

19. Das, B. M., (2010). Principles of Geotechnical Engineering. 7th Edition. Stamford, USA: Cengage Learning.

20. O'Kelly, B.C. and Pichan, S.P., Effects of Decomposition on the Compressibility of Fibrous Peat- A Review, Geomech. Geoeng. 8(4), 286-296 (2013).

21. Barnes, D.M., Monotonic and cyclic shear response of reconstituted natural silt. The University of British Columbia: Degree of Master (2015).

22. Yusoff, S.A.N.M, Bakar, I., Wijeyesekera, D.C., Zainorabidin, A.,Madun, A., Comparison of Geotechnical Properties of Laterite, Kaolin and Peat. Applied mechanics and material 773, 1438-1442 (2015).

23. Wong, L.S., Hashim, R. and Ali, F.H., A Review On Hydraulic Conductivity and Compressibility of Peat. Journal of Applied Sciences, 9: 3207-3218 (2009).

24. Mitchell, J.K., Fundamentals of Soil Behavior. J. Wiley and Son Inc (1993). 